\title{
OWnership Governance and Performance in SPANISH-MOROCCAN JOINT VENTURES
}

\author{
Maria Victoria Lopez-Perez, Maria Carmen Perez-Lopez \\ and Lazaro Rodriguez-Ariza \\ Department of Accounting and Finance, University of Granada
}

Accepted: March 2013

\begin{abstract}
This paper analyses the impact of ownership on performance by SMEs formed as Spanish-Moroccan international joint ventures (IJVs). In such SMEs, the functions and persons involved at different levels of governance - ownership, board and managers - often overlap. The results obtained from 210 SMEs suggest that owners often exert control by participating in the other mechanisms of governance. Their participation as members of the board has a positive influence on performance and thus the success of the IJV, but when owners form part of the management team (a less frequent situation), the influence on performance is negative and not significant. Participation by owners in the management team is not associated with the IJV's performance.
\end{abstract}

Key words: international Joint ventures, SMEs, corporate governance, ownership, performance

JEL: C35, F23, G32, M16

\section{1}

\section{Introduction}

The international joint venture (IJV) is one of the most important means by which companies, including SMEs, expand their activities and exploit opportunities to do business abroad (Morh \& Puck, 2005). The foreign firm seeks a local partner who knows the market, the culture, the financial institutions and possible tax advantages and ensures that the resulting IJV is considered a local firm. Thus, the creation of an IJV is a means of achieving entry into a new market. Few studies of IJVs, however, have focused on SMEs, although this is a very common means by which such firms seek access to new markets (Donckels \& Lambrecht, 1995; Kirby \& Kaiser, 2003), while their circumstances and characteristics are different from those of large firms (Hollenstein, 2005). One such difference is that SMEs are more likely to fail on account of limited resources (Buckley, 1989; Kirby \& Kaiser, 2003). Accordingly, it is important to analyse which factors in SMEs constituted as IJVs determine the success or otherwise of this relationship. In this paper, we focus specifically on their organizational structure. An IJV can be established as either an equity-based relationship or as a contract between partners (Berra, Piatti \& Vitali, 1995; Donckels \& Lambrecht, 1995); in the present study, we examine the first of these cases, in which there are at least two partners from different countries. The question of owners' strategies in IJVs is an important issue in studies on international business affairs (Gomes-Casseres, 1989; Hennart, 1991), and may be addressed from diverse theoretical standpoints; here, we consider the transaction cost theory (TCE). SMEs have few shareholders, who are usually closely involved in the day-to-day affairs of the company. This situation makes it unlikely that the classical agency problem of large companies, i.e. conflicts between principal and agent, will occur. Therefore, we examine a broader scenario in which contractual arrangements are established: the TCE. The basic idea of TCE is to recognize that, in a world of positive transaction costs, exchange agreements must be governed and that some forms of governance are better than others (Macher \& Richman, 2006). With respect to IJVs, TCE has been applied mainly in examining forms of entry to markets and agreements on capital structure (Brouthers, 2002), but no detailed 
research has been carried out on the question of governance structure and ownership. From the TCE standpoint, the complexity and composition of governance structure respond to the risks of opportunism and the existence of possible conflicts. The risks of opportunism can lead owners to establish different levels of governance. In the case of SMEs resulting from IJVs, the organizational structure chosen could include the participation of partners in some or all of the firm's governance mechanisms: ownership, board and managers (Rediker \& Seth, 1995; Zhara \& Pearce, 1989).

From an agency perspective, in respect of ownership, studies have examined, firstly, how factors such as the degree of concentration impact on performance (Demsetz \& Villalonga, 2001). Secondly, the existence of a board of directors may align the interests of managers and owners (Adjaoud, Zeghal \& Andaleeb, 2007) and its activity may influence company performance (Huse, 2000; Zhara \& Pearce, 1989). Thirdly, the characteristics of the management team could explain organizational outcomes (Finkelstein \& Hambrick, 1996). In the context of SMEs, another type of governance structure more suitable to this reality might be considered. Owners can control activities and influence company performance by monitoring managers or by participating at different levels of governance.

In many companies, and especially among SMEs, the same people can be found at different levels of governance and their functions often overlap (Huse, 1990). Sometimes companies are managed by their owners, or the latter form part of the board, and then governance functions are unified. The case of owner-directors and owner-managers frequently occurs in SMEs. In the case of IJVs, an additional factor is the interaction among partners, who may not necessarily share the same goals (Schaan \& Beamish, 1988) and one or several of them may act opportunistically (Williamson, 1991). The governance structure finally adopted should reflect these aspects.

Control is an important issue in the success of any IJV, and presents specific characteristics in SMEs. The aim of this research is to analyse how the mechanisms of control exerted by the owners of an SME created as an IJV may enhance company performance. To do so, we first considered the different ways in which partners exert control over firms, specifically, through their participation in different mechanisms of governance. The idea is that the model proposed for large companies may not be suitable for SMEs. In the latter case, there are few shareholders and the roles of ownership, board and managers usually overlap. Therefore, what is needed is a model that takes these aspects into account. Secondly, we examine which of these mechanisms of owners' control impact on performance. This question is one of great importance, as the continuity of such an alliance depends on whether the expected outcomes are achieved.

In this paper, we study the case of SMEs set up as joint ventures between companies from Spain and Morocco. Various trade agreements exist between these two countries, and Morocco enjoys a strategic location that facilitates access to markets in the Middle East and the rest of Africa (Economic and Commercial Office of Spain in Rabat, 2010). The results of this study could be extended to other IJVs between partners from European and African or Arab countries, or between those with similar characteristics (in cultural or trade agreements or agreements with emerging countries).

The rest of this paper is organised as follows: in the next section we discuss previous research and introduce our hypotheses. Section 3 presents the research methods applied and sections 4 and 5 set out the results achieved and discusses their implications. Our conclusions and the limitations acknowledged are stated in section 6 .

\section{2}

\section{Literature review and hypotheses}

The goal of this study is to analyse how ownership affects company performance, via the different mechanisms of governance. Accordingly, we examine how the concentration of ownership and the participation of owners on the board and in management impact on performance.

\subsection{Ownership}

The relation between performance and ownership structure has been widely addressed in the 
literature on corporate governance. Ownership constitutes an important element in the control of IJVs (Hill \& Hellriegel, 1994). The risk of opportunistic behaviour on the part of one or more partners (Williamson, 1991) has led to the adoption of diverse control mechanisms. In this respect, the degree of concentration of ownership is a factor in the risk of expropriation of resources (Oviatt \& McDougall, 1994); in addition, it reflects partners' capacity to influence managers. The presence of significant shareholders in ownership facilitates the process of controlling day-to-day management; this concentration of power enables owners to limit managers' discretionality and to eliminate inefficiencies arising from their actions (Shleifer \& Vishny, 1997).

With respect to the effects of ownership structure on company performance, some empirical studies have concluded that the control exercised by owners tends to improve the quality of management decisions and performance (Shleifer \& Vishny, 1997; Wiklund, Davidsson \& Delmar, 2003).

Another question that should be taken into account is that of the specific relations arising when an IJV is established. Each partner may have different requirements or objectives, and these may be divergent or in conflict with those of the other partners (Perrini, Rossi \& Rovetta, 2008). A high concentration of ownership could enable one partner to control the decision-making process (Blodgett, 1992; Killing, 1983), to appoint managers (Mjöen \& Tallman, 1997) and to reduce the scope for opportunistic behaviour on the part of the other partners.

On the other hand, an equally-shared ownership can be an indicator of the degree of collaboration and commitment on the part of each partner (Mjöen \& Tallman, 1997). A situation of balance among the partners could increase the level of perceived security and minimise the fear of exploitation or opportunism (Steensma \& Lyles, 2000).

We hypothesise that there is no relationship between ownership concentration and performance, since both ownership concentration and equally-shared ownership may have a positive effect on performance. The ownership structure depends on the possibility of opportunism, collaboration relationship or cultural differences between partners (Nakamura, 2005). Sometimes a concentration of ownership is necessary for the company to achieve its objectives, and at other times it is not. In every situation, the partners must determine the structure that will optimise their outcomes. Accordingly, we establish the following Hypothesis 1:

Hypothesis 1. In Spanish-Moroccan IJVs, the existence of ownership concentration has no effect on company performance.

\subsection{Owner directors}

In IJVs between Spanish and Moroccan firms, the existence of a board can be related to the establishment of formal, coercive channels in the organizational structure to control performance (Lopez-Perez, Gomez-Miranda, Rodriguez-Ariza \& Benghazi-Akhlaki, 2009). A single partner may be in a weak position against opportunistic action by top managers or other partners, and the board can constitute an effective channel of communication between partners and management (Adjaoud et al., 2007). In IJVs and SMEs, the representation by partners on the board is a reflection of the ownership composition (Huse, 1990; Killing, 1983; Schaan \& Beamish, 1988). In the field of IJVs, governance mechanisms provide a means of satisfying the (sometimes conflicting) interests of the partners in the alliance.

The board performs different roles, including advisory, strategic, control and monitoring functions (Raheja, 2005; Zhara \& Pearce, 1989); many studies have focused on the control function performed by boards in IJVs (Bjorkman \& Lu, 1999; Child \& Yan, 1999).

In the context of SMEs, the different governance mechanisms frequently overlap (Brunninge, Nordqvist \& Wiklund, 2007; Mustakallio, Autio \& Zahra, 2002). In this context, the role of the board and the arrangements between partners are different from those found in large firms. The participation of owners at different levels of governance enables them to defend their own interests and to control opportunism. The agreements between partners can lead owners to be present at different levels of governance. Thus, the participation of owners on the board could enhance performance, by controlling the 
risks of opportunism and preventing conflicts. It can also provide an effective means of controlling directors' actions (the possible entente between management and board (Carver, 2000)), enabling owners to obtain internal information and hence influence decisions. The advisory role played by ownerdirectors on behalf of shareholders could also improve the performance of the firm (Walsh \& Seward, 1990). When the board is independent of management, it is better able to monitor managers (Shleifer \& Vishny, 1997), which can lead to better performance. Finally, the board's possession of direct, detailed information on internal processes may stimulate managers to better perform their tasks (Cowling, 2003; Kim \& Sorensen, 1986).

Wagner, Stimpert \& Fubara (1998) observed a positive relation between owners' presence on the board and company performance, while many studies have reported the existence of such a positive relation in emerging markets (Klapper \& Love, 2004). Furthermore, in SMEs in which board members hold a higher proportion of equity, these boards tend to be more active in developing company objectives (Huse, 1990) and achieving a better performance (Keasey, Short \& Watson, 1994).

Within SMEs constituted as IJVs, the existence of owner-directors ensures that partners' interests are defended and the risk of opportunism is reduced. Therefore, the effect on performance is expected to be positive. Accordingly, hypothesis 2 is proposed as follows.

Hypothesis 2. In Spanish-Moroccan IJVs, the presence of owner-directors has a positive effect on company performance.

\subsection{Owner managers}

The characteristics of the management team account for a significant proportion of the outcomes achieved by an organization (Finkelstein \& Hambrick, 1996), so its actions can affect the functioning of the IJV (Hambrick, 1994). Company performance is thus a reflection of the characteristics and actions of the firm's executive managers, or top management team (Hambrick \& Mason, 1984).

The effect of this management team on performance may be closely related to its position vis-à-vis the partners. In IJVs, the managers' power is influenced by the control structure established by the partners (Geringer \& Hebert, 1989), whose expectations sometimes differ (Schaan \& Beamish, 1988) and managers have to look for a balance between the priorities and goals of the different partners (Petrovic, Kakabadse \& Kakabadse, 2006).

In an IJV, the selection of the managerial team is usually agreed among the partners involved. Ownership can be concentrated in one or two partners, and in this case there exists the risk that any conflicts between them may be translated to the managers who represent their interests. Top managers contribute their experience and knowledge, but, in addition, they usually represent their respective partners (Newman, 1995; Ensley \& Pearson, 2005).

In a context of SMEs, owners may act as managers, thus creating an identity between ownership and management, a situation that may or may not improve performance. The personal aims of such owner-managers will be aligned with those of the company, which should have a positive effect upon performance. In this sense, we would expect a positive relation between the presence of ownermanagers and company performance. However, if only one of the partners takes responsibility for management decisions, there might more readily be situations of conflict, and there would be a greater possibility of opportunistic behaviour. A management team comprised of owner-managers could have personal interests and non-independence in its actions (Raheja, 2005). The managers would seek to attain their own objectives, which would not necessarily have a positive effect on performance. Several empirical studies have provided insights into the relationship between owner-managers and performance in large companies, but their results are not transferable to the context of SMEs (Huse, 2000) or IJVs.

In the present study, we seek to determine the extent to which the identification of the management team with the ownership enhances company performance. Thus, we propose the following hypothesis:

Hypothesis 3. In Spanish-Moroccan IJVs, the existence of owner managers has a direct and positive effect on company performance. 


\subsection{Performance}

In the literature on the influence of corporate governance mechanisms on company performance, the latter is normally measured using objective variables based on accounting data and market information. The instruments used include return on assets, return on equity, return on sales, Tobin's q or market to book (Dehaene, De Vuyst \& Ooghe, 2001; Demsetz \& Villalonga, 2001; Villalonga \& Amit, 2006). In many countries, including Morocco, financial information on small companies is not normally available, and databases including this information are often non-existent. Consequently, researchers commonly use financial measures based on perception, which is also the case in the field of IJVs (Killing, 1983; Rauch, Wiklund, Lumpkin \& Frese, 2009). Furthermore, studies have shown that objective and subjective measures are correlated (Geringer \& Hebert, 1991; Glaister \& Buckley, 1998). In the present study, we use the degree of satisfaction attained (Covin \& Slevin, 1989), a subjective measure. Following the approach adopted by the above authors, we measured performance by the importance and satisfaction expressed by partners about the IJV's sales, sales growth, cash flows, gross and net profit margin, return on sales and return on investment.

\section{3}

Data and methods

\subsection{Sample selection}

This study was designed to analyse IJVs between Spanish and Moroccan companies carrying out their activities in Morocco. Following the methodology adopted in other studies of IJVs (Bjorkman \& Lu, 1999; Child \& Yan, 1999; Geringer \& Hebert, 1991), a structured survey was addressed to the CEOs of companies constituted as equity-based IJVs between Spanish and Moroccan SMEs. In accordance with the information provided by the Moroccan Ministry of Foreign Trade, in September 2009 there were 645 SMEs formed as Spanish-Moroccan IJVs. In this study, we used the definition of SMEs proposed by the European Commission, i.e., a company that employs fewer than 250 employees (Commission Recommendation 2003/361/EC).

The questionnaire was comprised of 33 questions in which a total of 52 issues were addressed. The questionnaire was presented telephonically during October 2009. We received 231 replies, which represented a response rate of 32.5 percent. Of these, 21 replies were discarded because they were incomplete, incorrectly expressed or else they corresponded to large companies. The final sample was comprised of 210 valid surveys of SMEs, of which 65 percent were small and 35 percent medium-sized; 30 percent were controlled by a board of directors and 70 percent by a single director. The confidence level was established at 95 percent, with a sampling error of 5.6 percent.

\subsection{Variables and measures}

Dependent variable. The dependent variable used was performance. As stated above, the Covin and Slevin scale (Covin \& Slevin, 1989) was employed as a subjective measure of financial performance. We measured financial performance according to perceptions of sales, sales growth, cash flow, gross and net profit margin, return on sales and return on investment, with all data referring to 2009 . We thus obtained a weighted average performance index for each firm. The mean score was 11.94; the standard deviation was 3.75 , with a range of 3.8 to 24.5 and a Cronbach alpha score of 0.94 was recorded.

In countries such as Morocco, where there is usually no legal obligation to disclose financial information, a subjective variable must be used to measure business success. Prior to our analysis, however, we examined the relationship between subjective and objective measures. The correlations between the objective and subjective variables were calculated for 76 data items, corresponding to the number of firms for which objective measures of financial performance were available (Dess \& Robinson, 1984). The results obtained (Table 1) show that the subjective and objective variables used to measure performance do indeed correlate, so the subjective measure can be used to measure performance. 


\section{Table 1}

Correlations for objective and subjective variables (Pearson Coefficient)

\begin{tabular}{|c|c|c|c|c|c|}
\hline & & \multicolumn{4}{|c|}{ Objective Performance Measures $(n=76)$} \\
\hline & & $\begin{array}{l}\text { Growth } \\
\text { in sales }\end{array}$ & $\begin{array}{l}\text { Return on } \\
\text { assets }\end{array}$ & $\begin{array}{l}\text { Return } \\
\text { on equity }\end{array}$ & $\begin{array}{c}\text { Overall } \\
\text { company } \\
\text { performance }\end{array}$ \\
\hline \multirow{4}{*}{$\begin{array}{l}\text { Subjective Performance } \\
\text { Measures }(n=76)\end{array}$} & Growth in sales & 1 & & & \\
\hline & Return on assets & $0.63^{* *}$ & 1 & & \\
\hline & Return on equity & 0.54 & $0.60^{* *}$ & 1 & \\
\hline & Overall company performance & 0.30 & $0.43^{*}$ & $0.67^{*}$ & 1 \\
\hline
\end{tabular}

Independent Variables. Ownership is described by means of three variables: one for ownership concentration and two for the presence of ownership in other governance mechanisms. These variables enable us to study the possible correlation between ownership and board, and between ownership and management.

The measure of ownership concentration (BLOCKHOLDER) is calculated using the percentage of shares held by the partners. A categorical variable was constructed, with three possible values: 0 in the case of no blockholders; 1 for balanced holdings among the partners; and 2 for a majority holding by one of the partners.

To describe the shareholdings of the top executives and other board members, two dichotomous variables were used (Linck, Netter \& Yang, 2008); the first, DIRECTOR $O W N E R$, addresses whether members of the board and their families are owners. This variable takes a value of 0 when board members are not owners (21 percent of the cases) and a value of 1 otherwise (79 percent of the cases). The second variable, MANAGEMENT-OWNER, takes a value of 0 when the CEO, the top management team and their families are not owners (78 percent of the cases), and 0 , otherwise (22 percent of the cases).

Control variables. Although in SMEs the board of directors usually exists only on paper, there are companies that have active boards which are strongly engaged in the company's activities. In any case, SMEs normally have small boards of directors (Cowling, 2003). The participation and involvement of the board may be studied in relation to its size, $B O A R D$ $S I Z E$, measured by the number of directors
(Linck et al., 2008; Markarian, Parbonetti \& Previts, 2007), and by BOARD MEETING, measured by the number of board meetings held annually (Sapienza, Manigart \& Vermeir, 1996).

The size of the top management team can also influence performance. In the context of SMEs, the fact of a small number of executives might promote efficiency, via greater proximity to the owners. On the other hand, the existence of a large number of managers might reflect conflicting interests among partners. In the case of joint ventures, each partner may try to influence management and defend its interests; but the existence of a more powerful partner could decisively influence the size and composition of the management team and alignment (Child \& Yan, 1999). Moreover, the size of the top management team provides a measure of the greater or smaller quantity of resources and skills available for decisionmaking. In companies with small management teams (as may occur in SMEs), it is more difficult to distribute responsibilities and to establish diverse functional areas (Bantel \& Jackson, 1989). On the other hand, large management teams may enjoy greater possibilities for problem-solving, owing to the existence of a greater volume of data, more critical judgements in the analytical process, an increased number of possible strategies to achieve solutions and a larger range of perspectives to bring to bear upon a problem (Hoffman \& Maier, 1961). However, although large groups present considerable advantages, their size may also bring about problems of coordination and communication, which do not affect small groups (Blau, 1970). TOP MANAGEMENT TEAM was recorded as the 
number of members of the top management team (Ensley \& Pearson, 2005).

Other control variables included were the company size (FIRM SIZE), measured by the number of employees, its maturity (FIRM $A G E$ ), determined by the number of years the company has been active, and the industry (INDUSTRY), distinguishing between manufacturing and trading companies.

\section{4}

\section{Analysis and results}

Table 2 shows the correlations and the descriptive statistics for the variables analysed in this study. There is a negative correlation between performance and board size and the number of board meetings, and a positive relation between performance and firm age, and firm size and the existence of ownerdirectors. We found a negative correlation between the existence of owner-directors and board size, and also with the number of board meetings. Moreover, the existence of ownermanagers is negatively associated with the size of the management team. Finally, the existence of blockholders is negatively associated with the number of board meetings. We found a correlation between firm size and board size, the number of board meetings, the size of the top management team, firm age (maturity) and the industry sector.

Table 3 shows the multiple linear regression analysis results used to test the hypotheses.

\section{Table 2}

Descriptive statistics and correlations for variables

\begin{tabular}{|c|c|c|c|c|c|c|c|c|c|c|c|c|c|}
\hline \multirow{2}{*}{\multicolumn{2}{|c|}{ Variables }} & \multirow{2}{*}{ Mean } & \multirow{2}{*}{ S.D. } & \multicolumn{10}{|c|}{ Correlations } \\
\hline & & & & 1 & 2 & 3 & 4 & 5 & 6 & 7 & 8 & 9 & 10 \\
\hline 1 & Performance & 13.11 & 4.22 & 1 & & & & & & & & & \\
\hline 2 & Board size & 1.50 & 2.67 & $-0.20^{*}$ & 1 & & & & & & & & \\
\hline 3 & Board Meeting & 1.48 & 3.81 & $-0.24^{\star *}$ & $0.66^{* *}$ & 1 & & & & & & & \\
\hline 4 & Top Management Team & 3.96 & 4.68 & -0.03 & 0.02 & 0.02 & 1 & & & & & & \\
\hline 5 & Firm age & 13.76 & 8.83 & $0.14^{*}$ & 0.07 & 0.08 & 0.10 & 1 & & & & & \\
\hline 6 & Firm size & 65.36 & 15.21 & $0.15^{*}$ & $0.20 *$ & $0.19^{*}$ & $0.33^{* *}$ & $0.24^{* *}$ & 1 & & & & \\
\hline 7 & Sector & 0.75 & 0.43 & -0.04 & -0.02 & 0.08 & -0.08 & 0.05 & $-0.16^{*}$ & 1 & & & \\
\hline 8 & Director Owner & 0.80 & 0.40 & $0.18^{*}$ & $-0.21^{*}$ & $-0.15^{\star}$ & 0.07 & -0.13 & -0.01 & -0.07 & 1 & & \\
\hline 9 & Management Owner & 0.22 & 0.42 & -0.05 & -0.15 & -0.09 & $-0.15^{*}$ & -0.07 & -0.07 & -0.12 & 0.03 & 1 & \\
\hline & Blockholder & 1.45 & 0.78 & -0.08 & 0.01 & $-0.08^{*}$ & 0.11 & 0.05 & 0.01 & 0.01 & 0.06 & 0.01 & 1 \\
\hline
\end{tabular}

Initially, the control variables included were those for industry, and company maturity and size (Model 1), in order to analyse the aspects accounted for by these variables. Of these, only company size was found to be a significant variable. The explanatory capacity of these control variables amounted to 14 percent of the variance. Subsequently, the control variables related to governance, board size, the number of board meetings and top management team size were incorporated (Model 2). The table shows that this set of control variables accounts for 19 percent of the variance. The significant variables were the number of board meetings and company size. The first of these presented an inverse relation, i.e. greater numbers of board meetings were associated with poorer performance, while company size was found to have a positive effect, i.e. large companies tend to achieve better levels of performance. The number of board meetings constitutes an explanatory variable, and board size is not significant. A certain degree of correlation was observed among the variables addressing the activity of corporate governance, which might account for the fact that only the number of board meetings is explanatory in the model. This fact suggests that the number of board meetings is more explanatory of company performance than is the board size. The other variables industry, company maturity and board size are not statistically significant. 
Table 3

Regression coefficients and statistics

\begin{tabular}{|c|c|c|c|}
\hline Dependent variable: Performance & Model 1 & Model 2 & Model 3 \\
\hline \multicolumn{4}{|c|}{ Independent variables } \\
\hline DIRECTOR_OWNER & & & $\begin{array}{l}0.18 \\
(0.00)^{* *}\end{array}$ \\
\hline MANAGEMENT_OWNER & & & $\begin{array}{c}-0.05 \\
(0.51)\end{array}$ \\
\hline BLOCKHOLDER & & & $\begin{array}{c}0.09 \\
(0.25)\end{array}$ \\
\hline \multicolumn{4}{|c|}{ Control variables } \\
\hline FIRM SIZE & $\begin{array}{c}0.20 \\
(0.00)^{*}\end{array}$ & $\begin{array}{c}0.20 \\
(0.00)^{*}\end{array}$ & $\begin{array}{l}0.21 \\
(0.01)^{\star *}\end{array}$ \\
\hline FIRM AGE & $\begin{array}{c}0.13 \\
(0.10)\end{array}$ & $\begin{array}{c}0.15 \\
(0.05)\end{array}$ & $\begin{array}{l}0.17 \\
(0.03)^{*}\end{array}$ \\
\hline INDUSTRY & $\begin{array}{c}0.04 \\
(0.67)\end{array}$ & $\begin{array}{c}0.02 \\
(0.85)\end{array}$ & $\begin{array}{c}0.03 \\
(0.75)\end{array}$ \\
\hline \multicolumn{4}{|c|}{ Governance control variables } \\
\hline BOARD SIZE & & $\begin{array}{l}-0.12 \\
(0.25)\end{array}$ & $\begin{array}{l}-0.09 \\
(0.36)\end{array}$ \\
\hline BOARD MEETING & & $\begin{array}{l}-0.24 \\
(0.00)^{* *}\end{array}$ & $\begin{array}{c}-0.22 \\
(0.00)^{\star *}\end{array}$ \\
\hline TOP MANAGEMENT TEAM & & $\begin{array}{l}-0.05 \\
(0.51)\end{array}$ & $\begin{array}{c}-0.07 \\
(0.27)\end{array}$ \\
\hline Adjusted R Square & 0.14 & 0.19 & 0.29 \\
\hline F-Statistic & 6.514 & 8.131 & 6.671 \\
\hline Probability & 0.01 & 0.00 & 0.00 \\
\hline
\end{tabular}

${ }^{* *} p<.01$

${ }^{*} p<.05$

In the following step (Model 3), the independent variables were introduced in order to test Hypotheses 1, 2 and 3. The inclusion of these variables in the model increases the amount of variance accounted for by the initial model. Examination of the regression coefficients shows that the presence of owners on the board does influence performance, so Hypothesis 2 is confirmed. As we hypothesised, the influence of block holders does not explain performance, and thus Hypothesis 1 is accepted. When ownership and management coincide, the relation with performance is inverse and non-significant. Thus, Hypothesis 3 is rejected. On the other hand, the control variables of maturity and size were found to be significant elements in accounting for company performance. The industry variable is not significant. In relation to the governance control variables, board meeting is a significant variable and presents an inverse relationship with respect to performance. Finally, neither the top management team variable nor that of board size was found to be significant.

\section{5}

\section{Discussion}

In this study, we examine the influence of ownership and its involvement in management on business performance. The context of IJVs between Spanish and Moroccan partners is characterised by the existence of a number of SMEs in which ownership is concentrated in a small number of partners. The owners normally participate in other mechanisms of corporate governance, mainly as members of the board. We must therefore analyse the influence of ownership, both directly and via participation in other governance structures, on performance.

The results of the regression analysis show that company performance is indeed affected by ownership, although its influence is exerted indirectly, through the board. On the one hand, when it comes to ownership, the results show 
that the relation between a high concentration of ownership and performance is positive, but not significant. Accordingly, Hypothesis 1 is accepted. In the Spanish-Moroccan IJVs analysed in this study, in most cases (66 percent) there was a blockholder. Only in 11 percent of IJVs was ownership shared 50 percent. In this context, it can be appreciated that the ownership structure adopted has no effect on performance. Each firm adopts the most appropriate ownership structure for the objectives of the partners, according to the agreement and the contributions to be made by each partner. Our sample consists of mature and successful firms (average firm age 14). The current ownership structure is suited to the interests of the owners. The owners use different control mechanisms to direct the decisions and also participate in other mechanisms of governance (Hill \& Hellriegel, 1994). There is a tendency to opt for a concentrated form of ownership, as in other emerging countries, possibly in order to protect owners from the dangers of expropriation and opportunism (Oviatt \& McDougall, 1994). Nevertheless, the form of ownership structure does not affect performance.

When the owners act as members of the board, this affects performance; in other words, the influence of owners on performance is effected through their participation on the board (Cowling, 2003; Sheiler \& Vishny, 1986). According to the results obtained from this study, boards of directors are usually relatively small, although this is not indicative of a less active board (Markarian et al., 2007), at least as far as performance goes. The proximity of owners enables them to exercise day-to-day supervision of the firm's activities, to control opportunism and to propose remedial action when necessary. Our study highlights the effectiveness of these actions. This role enables them to obtain internal information and to influence the decisionmaking process (Walsh \& Seward, 1990). Our study reveals that owner-directors act in the same ways as owners do when it comes to achieving their goals (Linck et al., 2008). Indeed, this explanatory variable was found to be the most significant of all those analysed. Thus, the task of these members of the board is to control and supervise the management of the firm. The results also demonstrate the independence of these board members from the top management team, as the latter exert a contrary effect on performance (Carver, 2000), although it is not a significant variable in the model.

In our sample, the proportion of ownermanagers was not very high (18 percent) with respect to owner-directors ( 80 percent). Most of the IJVs sampled maintained a separation between ownership and management. The correlation analyses performed show that the existence of owner-directors was associated with smaller management teams, which could be indicative of a certain proximity to the ownership (Child \& Yan, 1999). However, the participation of owners in the management team, though infrequent, is not associated with an improvement in the IJV's performance, which might reflect the existence of conflicts and opportunism on the part of the partner responsible for management activities (Morh \& Puck, 2005) who does not act independently (Raheja, 2005). Thus, the manager who is at the same time an owner will seek to attain his/her own goals, and take less account of the performance achieved by the IJV. We found that the actions by owner-managers were not aligned with those of the partners, and the relation, although not significant, was negative, so Hypothesis 3 cannot be accepted. This conclusion could reflect different interests among owner-managers and other partners.

Regarding the impact of board size and the number of board meetings on performance, we found the effect of both parameters to be negative. These variables correlate with performance, but their relationship is not significant in the regression model. SMEs normally have small boards of directors. The activity of the board and its influence, measured via the number of interactions (Sapienza et al., 1996), has a negative effect on company performance. The lack of positive results, or the perception of this, could imply a that more meetings were being held to find solutions. In addition, large boards might be related to the conflicts taking place between partners in the IJV.

In relation to the influence of the size of the top management team on company performance, the results obtained show that this factor is not significant, and it does not seem to 
affect the performance of IJVs (Finkelstein \& Hambrick, 1996; Hambrick \& Mason, 1984). Thus a large top management team does not imply positive effects on performance. The coefficient of the top: control may be exercised by owners through other mechanisms of governance; or the coefficient might be negative because efficiency in these firms is related to supervision by the IJV partners, and to the small number of top managers. This effect might also arise from the fact that the aims of top management do not coincide with those of owner-directors and owners; in this case, the power and predominant control of management are exercised by the board. This control mechanism then tends to replace managerial action. When performance is measured via the degree of satisfaction achieved, it is apparent that the parties' interests are disparate. The existence of partners with possibly divergent interests would induce the management team to act in accordance with its own aims and objectives or in favour of one partner over the others. This might explain the negative relation between the size of the top management team and company performance.

Finally, company performance is positively related to its size and age. Thus, in a longerestablished firm, the partners have overcome their possible differences and have agreed upon common goals. Firm size is also related positively to performance. Larger companies present greater partner satisfaction, perhaps because they are able to distribute functions and avoid conflicts in this way. Firm size is related to the presence of a larger board, to larger top management teams and to a higher frequency of board meetings. We found an inverse relationship between industry sector and firm size.

\section{6}

\section{Conclusions}

In SMEs, the role of ownership is very significant, to the extent that owners often intervene directly or through other governance management mechanisms (board and top management team). In IJVs between Spanish and Moroccan companies, the ownership is often highly concentrated, with a strong presence of owners on the board, which facilitates the alignment of goals between owners and managers, thus favouring satisfaction with the outcomes achieved. The two mechanisms of corporate governance coincide in focusing mainly on control of management in order to achieve objectives and produce a positive effect on company performance. SMEs normally have small boards of directors, an organizational structure that has a positive influence on performance. The board size and the number of board meetings might be related to the existence of problems between partners or to the need to resolve conflicts and find solutions.

Although studies have been conducted on the effects of ownership on the different mechanisms of governance, they have mainly examined separately the effects on performance of the existence of owner-managers and of owner-directors. Diverse effects on performance have been observed in this respect; potential differences between partners may be transferred to the management team, or management may exploit the partners' weaknesses in order to achieve its own goals. The present study highlights the important role played by owners in SMEs in the case of companies formed as IJVs.

According to the results obtained in this study, it is necessary to make a separation between control and management in order to ensure the satisfactory development of company activity, as these mechanisms have inverse effects on performance. In areas where there is a strong concentration of ownership and a limited number of partners, the control exercised over company activity is a deter-mining factor, and the role of top management then becomes subsidiary and has no significant effect on company performance. This control is more effective when owners are involved as board members. Our results show that the top management team is not aligned to owners. When owners cannot trust management, they develop other mechanisms of governance (for example, via a strong board or direct control) or else they become involved as ownerdirectors.

Experience and size are related to performance. With greater experience, an organizational culture can accumulate to solve conflicts and to avoid opportunism, thus 
improving performance. A positive effect on performance is also obtained by greater firm size, enabling it to allocate functions and avoid possible conflict.

The results obtained in this study could be extended to other IJV experiences with similar cultural characteristics, such as those involving European and Arab or African companies.

Let us point out some limitations of the present study. In the first place, the fact that results were obtained by means of questionnaires means that a certain degree of subjectivity was introduced. We attempted to overcome this by using generally-accepted tests to ensure reliability and by using objective performance data, but there is always the possibility of some bias affecting the results. Furthermore, we examined companies that are active in different sectors and with different systems of governance, which enabled us to increase the generalization of our results, but also led to some heterogeneity that would have been avoided by the use of totally uniform samples. It should also be observed that, although the model obtained provides a good account of the variance, the mechanisms of governance and its goals constitute a complex issue for study, and that further examination of various aspects is required, such as the strategic objectives, which might be more representative of the fundamental justification for the IJV. Finally, we have focused on ownership, but there may be many other mechanisms (outsiders, CEO duality) that could provide a more complete explanation of company performance.

\section{References}

ADJAOUD, F., ZEGHAL, D. \& ANDALEEB, S. 2007. The effect of board's quality on performance: A study of Canadian firms. Corporate Governance: An International Review, 15:623-635.

BANTEL, K.A. \& JACKSON, S.E. 1989. Top management and innovations in banking: Does the composition of the top team make a difference? Strategic Management Journal, 10:107-124.

BERRA, L., PIATTI, L. \& VITALI, G. 1995. The internationalization process in the small and medium sized firms: A case study on the Italian clothing industry. Small Business Economics, 7(1):67-75.

BLAU, P.M. 1970. A formal theory of differentiation in organizations. American Sociological Review, 35:201-218.

BLODGETT, L. 1992. Factors in the instability of international joint ventures: An event history analysis, Strategic Management Journal, 13(6):475-481.

BJORKMAN, I. \& LU, Y. 1999. The management of human resources in Chinese-Western joint ventures. Journal of World Business, 34(3):306-324.

BROUTHERS K.D. 2002. Institutional, cultural and transaction cost influences on entry mode choice and performance. Journal of International Business Studies, 33(2):203-221.

BRUNNINGE, O., NORDQVIST, M. \& WIKLUND, J. 2007. Corporate governance and strategic change in SMEs: The effects of ownership, board composition and top management teams. Small Business Economics, 29: 295-308.

BUCKLEY, P.J. 1989. Foreign direct investment by small and medium sized enterprises: The theoretical background. Small Business Economics, 1(2):89-100.

CARVER, J. 2000. The opportunity for re-inventing corporate governance in joint ventures companies. Corporate Governance: An International Review, 8(1):75-80.

CHILD, J. \& YAN, Y. 1999. Investment and control in international joint venture: The case of China. Journal of World Business, 34:3-15.

COVIN, J.G. \& SLEVIN, D.P. 1989. Strategic management of small firms in hostile and benign environments. Strategic Management Journal, 10(1):75-87.

COWLING, M. 2003. Productivity and corporate governance in smaller firms. Small Business Economics, 20:335-344.

DEHAENE, A., DE VUYST, V. \& OOGHE, H. 2001. Corporate performance and board structure in Belgian companies. Long Range Planning, 34:383-398.

DEMSETZ, H. \& VILLALONGA, B. 2001. Ownership structure and corporate performance. Journal of Corporate Finance, 7:209-233. 
DESS, G.G. \& ROBINSON, R.B. 1984. Measuring organizational performance in the absence of objective measures: The case of the privately-held firm and conglomerate business unit. Strategic Management Journal, 5(3):265-273.

DONCKELS, R. \& LAMBRECHT, J. 1995. Joint ventures: No longer a mysterious world for SMEs from developed and developing countries. International Small Business Journal, 13(2):10-26.

ECOMOMIC AND COMMERCIAL OFFICE OF SPAIN IN RABAT. 2010. 52 more frequent questions on investment in Morocco. Available at: http://www.oficinascomerciales.es/icex/cda/controller/pageOfecomes/ 0,5310,5280449_6239376_5287111_4298112_MA,00.html [accessed 2012-04-15].

ENSLEY, M.D. \& PEARSON, A.W. 2005. An exploratory comparison of the behavioral dynamics of top management teams in family and nonfamily new ventures: Cohesion, conflict, potency, and consensus. Entrepreneurship: Theory and Practice, 29:267-284.

FINKELSTEIN, S. \& HAMBRICK, D.C. 1996. Strategic leadership: Top executives and their effects on organizations. West, St Paul, MN.

GERINGER, J.M., HEBERT, S. 1989. Control and performance of international joint ventures. Journal of International Business Studies, 20(2):235-254.

GERINGER, J.M. \& HEBERT, L. 1991. Measuring performance of international joint ventures, Journal of International Business Studies, 22(2):249-263.

GLAISTER, K.W. \& BUCKLEY, P.J. 1998. Measures of performance in UK international alliances. Organization Studies, 19(1):89-118.

GOMES-CASSERES, B. 1989. Ownership structures of foreign subsidiaries. Journal of Economic Behavior \& Organization, 11(1):1-25.

HAMBRICK, D.C. 1994. Top management groups: A conceptual integration and reconsideration of the "team", in Cummings L.L. (ed.) Research in Organizational Behaviour. JAI Press, Greenwich CT:171-213.

HAMBRICK, D.C. \& MASON, P.A. 1984. Upper echelons: The organization as a reflection of its top managers, Academy of Management Review, 9:193-206.

HENNART, J.F. 1991. The transaction cost theory of joint ventures: An empirical study of Japanese subsidiaries in the United States. Management Science, 37(4):483-497.

HILL, R.C. \& HELLRIEGEL, D. 1994. Critical contingencies in joint venture management: Some lessons from managers. Organization Science, 5(4):594-607.

HOFFMAN, L.R. \& MAIER, N.R.F. 1961. Quality and acceptance of problem solutions by members of homogeneous and heterogeneous groups. Journal of Abnormal and Social Psychology, 58:27-32.

HOLLENSTEIN, H. 2005. Determinants of international activities: Are SMEs different? Small Business Economics, 24(5):431-450.

HUSE, M. 1990. Board composition in small enterprises, Entrepreneurship \& Regional Development, 2:363- 373 .

HUSE, M. 2000. Boards of directors in SMEs: A review and research agenda. Entrepreneurship and Regional Development, 12(4):271-290.

KEASEY, K., SHORT, H. \& WATSON, R. 1994. Director's ownership and the performance of small and medium sized firms in the UK. Small Business Economics, 6(2):225-236.

KILLING, P.J. 1983. Strategies for joint venture success. New York: Praeger.

KIM, W. \& SORENSEN, E. 1986. Evidence on the impact of the agency costs of debt on corporate debt policy, Journal of Financial and Quantitative Analysis, 21(June):131-144.

KIRBY, D.A. \& KAISER, S. 2003. Joint ventures as an internationalization strategy for SMEs. Small Business Economics, 21:229-242.

KLAPPER, L.F. \& LOVE, I. 2004. Corporate governance, investor protection and performance in emerging markets. Journal of Corporate Finance, 10:703:728.

LINCK, J.S., NETTER, J.M. \& YANG, T. 2008. The determinants of board structures, Journal of Financial Economics, 87:308-328.

LOPEZ-PEREZ, M.V., GOMEZ-MIRANDA, M.E., RODRIGUEZ-ARIZA, L. \& BENGHAZI-AKHLAKI, H. 2009. Key factors in conflict resolution in strategic alliances between Spanish and Moroccan companies. In Reynolds, J.V. (ed.) Emerging markets: identification, new development and investment. Hauppauge, NY: Nova Science Publishers. 
MACHER, J.T. \& RICHMAN, B.D. 2006. Transaction cost economics: An assessment of empirical research in the social sciences. Duke Law School Faculty Scholarship Series, Duke Law School, Duke.

MARKARIAN, G., PARBONETTI, A. \& PREVITS, G.J. 2007. The convergence of disclosure and governance practices in the world's largest firms. Corporate Governance: An International Review, 15(2):294-310.

MJÖEN, H. \& TALLMAN, S. 1997. Control and performance in international joint ventures. Organization Science, 8(3):257-274.

MORH, T. \& PUCK, J.F. 2005. Managing functional diversity to improve the performance of international joint ventures, Long Range Planning, 38:163-182.

MUSTAKALLIO, M., AUTIO, E. \& ZAHRA, S.A. 2002. Relational and contractual governance in family firms: Effects on strategic decision making. Family Business Review, 15(3):205-222.

NAKAMURA, M. 2005. Joint venture instability learning and the relative bargaining power of the parent firm, International Business Review, 14:465-493.

NEWMAN, W.H. 1995. Stages in cross cultural collaboration. Journal of Asian Business, 11(4):69-74.

OVIATT, B.M. \& MCDOUGALL, P.P. 1994. Toward a theory of international new ventures, Journal of International Business Studies, 25(1):45-64.

PERRINI, F., ROSSI, G. \& ROVETTA, B. 2008. Does ownership structure affect performance? Evidence from the Italian market. Corporate Governance: An International Review, 16(4):312-325.

PETROVIC, J., KAKABADSE, A. \& KAKABADSE, N. 2006. International joint venture (IJC) directors' contribution to board effectiveness: Learning from the literature. Management Decision, 44(3):346-366.

RAHEJA, C. 2005. Determinants of board size and composition: A theory of corporate boards. Journal of Financial and Quantitative Analysis, 40:283-306.

RAUCH, A., WIKLUND, J., LUMPKIN, G.T. \& FRESE, M. 2009. Entrepreneurial orientation and business performance: An assessment of past research and suggestions for the future. Entrepreneurship Theory and Practice, 33(3):761-787.

REDIKER, K.J. \& SETH, A. 1995. Board of directors and substitution effects of alternative governance mechanisms. Strategic Management Journal, 16(2):85-99.

SAPIENZA, H.J. \& MANIGART, S. \& VERMEIR, W. 1996. Venture capitalist governance and value added in four countries. Journal of Business Venturing, 11:439-469.

SCHAAN, J. \& BEAMISH, A. 1988. How to control a joint venture even as a minority partner. Journal of General Management, 14(1):4-16.

SHLEIFER, A. \& VISHNY, R. 1986. Large shareholders and corporate control. Journal of Political Economy, 94:461-488.

SHLEIFER, A. \& VISHNY, R. 1997. A survey of corporate governance. Journal of Finance, 52:737-783.

STEENSMA H.K. \& LYLES M.A. 2000. Explaining IJV survival in a transitional economy through social exchange and knowledge-based perspectives. Strategic Management Journal, 21(8):831-851.

VILLALONGA, B. \& AMIT, B. 2006. How do family ownership, control and management affect firm value? Journal of Financial Economics, 80:385-417.

WAGNER, J., STIMPERT, J. \& FUBARA, E. 1998. Board composition and organizational performance: Two studies of insider/outsider effects. Journal of Management Studies, 35(5):655-677.

WALSH, J. \& SEWARD, J. 1990. On the efficiency of internal and external corporate control mechanisms, family firms and venture-capital backed firms. International Journal of Entrepreneurial Behaviour and Research, 10(1/2):85-105.

WIKLUND, J., DAVIDSSON, P. \& DELMAR, F. 2003. What do they think and feel about growth? An expectancy-value approach to small business managers' attitudes toward growth. Entrepreneurship: Theory and Practice, 27(3):247-270.

WILLIAMSON, O.E. 1991. Comparative economic organization: the analysis of discrete structural alternatives. Administrative Science Quarterly, 36(6):269-296.

ZHARA, S.A., PEARCE, J.A. 1989. Board of directors and corporate financial performance: A review and integrative model. Journal of Management, 15:291-334. 